\title{
Nilai-Nilai Psiko-Edukatif Dalam Surat Al-'Ashar: (Pembacaan Kritis Atas Pemikiran M.Quraish Shihab dalam Tafsir al-Misbah)
}

\author{
Dr. Rahmad Hidayat., M.Ag., M.Pd \\ Sekolah Tinggi Agama Islam Negeri Curup
}

\begin{abstract}
Abstrak
Sebagai mana yang telah sama-sama diketahui bahwa al-Qur'an merupakan pedoman normatif - teoritis dalam pelaksanan pendidikan agama Islam. Didalamnya terdapat nilai-nilai edukatif dan antara lain adalah nilai-nilai edukatif dalam Surat al-'Ashr. Nilai-Nilai Edukatif dalam Surat al-'Ashr (Pembacaan Kritis Atas Pemikiran M.Quraish Shihab dalam Tafsir al-Misbah) adalah merupakan penelitian yang bertujuan untuk mendeskripsikan dan menganalisis secara kritis tentang Nilai-nilai Pendidikan yang terdapat dalam surat al-'Ashr kaitannya dengan penafsiran M.Quraish Shihab, serta bagaimana relevansinya dalam hal pelaksanaan dan upaya peningkatan kualitas Pendidikan Agama Islam. Penelitian ini merupakan penelitian pustaka (libarary research), dengan teknik pengumpulan datanya yang dilakukan melalui dokumentasi. Pendekatan yang dipakai dalam penelitian ini adalah pendekatan Paedagogik. Artinya pembahasan yang ada dalam penelitian ini mengacu kepada konsep yang ada dalam al-Qur'an dan al-Sunnah berdasarkan atas hasil penafsiran dari M.Quraish Shihab. Adapun analisis datanya secara kualitatif dilakukan dengan instrumen analisis deduktif-induktif. Metode deduktif ditempuh untuk mengungkap atau men-generalisasikan nilai-nilai pendidikan dalam surat al-'Ashr sebagaimana terdapat dalam kitab Tafsir al-Misbah yang merupakan pokok-pokok pemikiran atau hasil penafsiran dari M.Quraish Shihab, sehingga dapat diperoleh kesimpulan yang utuh. Sedangkan metode induktif dipergunakan untuk mengambil nilai-nilai pendidikan tersebut untuk selanjutnya dikembangkan ke dalam kerangka umum nilai-nilai pendidikan Agama Islam.
\end{abstract}

Key Word: al-Qur'an- Nilai-Nilai Pendidikan-Tafsir M.Qurasih Shihab 


\section{PENDAhUluAN}

\section{A. Latar Belakang Masalah}

Sejak awal kehadirannya, Islam telah memberikan perhatian yang begitu besar terhadap penyelenggaraan pendidikan dan pengajaran dalam arti seluas-luasnya. ${ }^{1}$ Hal ini antara lain, dapat dilihat pada apa yang secara normatif ditegaskan dalam al-Qur'an dan al-Hadis, dan pada apa yang secara empiris dapat dilihat dalam sejarah. Secara normatif, sumber ajaran Islam, al-Qur'an dan al-Hadis diakui sebagai pedoman hidup yang dapat menjamin keselamatan hidup di dunia dan akhirat, amat memberikan perhatian yang besar terhadap pendidikan. Demikian pula secara empiris-historis umat Islam telah memainkan peranan yang signifikan dalam hal pendidikan yang hasilnya kini masih dapat dirasakan. ${ }^{2}$ Dalam agama Islam, al-Qur'an merupakan sumber nilai yang absolut (mutlak) dan keberadaannya tidak mengalami perubahan walaupun penafsirannya dimungkinkan mengalami perubahan sesuai dengan konteks atau keadaan, zaman dan tempat ( $s$ f $>>$ lih likulli zama $>n$ wa maka $>n$ ).

Disamping itu, al-Qur'an merupakan pedoman normatif - teoritis dalam pelaksanan pendidikan agama Islam. Firman yang tertuang dalam al-Qur'an merupakan das Solen yang harus diterjemahkan menjadi das Sein oleh para ahli dikalangan pendidik menjadi suatu rumusan pendidikan Islam yang dapat menghantarkan pada sifat, nilai dan tujuan pendidikan yang hakiki.

Al-Qur'an seperti diketahui diturunkan oleh Allah Swt. sebagai petunjuk dan pedoman dalam kehidupan manusia di muka bumi. Dalam hal ini terdapat firman Allah Swt.. ${ }^{3}$

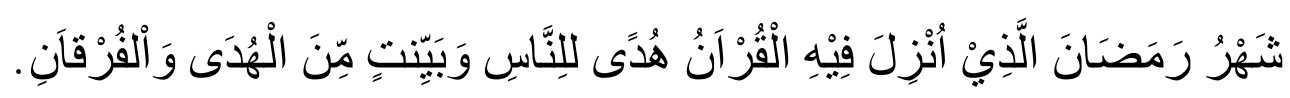

Artinya: "Bulan Ramadhan, bulan yang di dalamnya diturunkan kitab suci al-Qur'an sebagai petunjuk bagi manusia dan penjelasan-penjelasan mengenai petunjuk tersebut dan sebagai pembeda (antara yang hak dan yang bathil)."

Al-Qur'an datang dalam rangka memberikan pedoman kepada manusia, dengan demikian dapat diketahui tentang tingkah laku manusia antara yang positif dan negatif baik secara individu maupun secara kolektif guna menciptakan kehidupan yang baik dan tenteram di dunia dan akhirat. Realisasi lebih jauh, al-Qur'an memberikan petunjuk dengan jelas dan tegas, dimana al-Qur'an menyebutkan dirinya sebagai al-Furqa $>n$ (pemisah antara yang baik 
dan yang tidak baik). Makna tersebut dapat tersirat, namun kedua makna itu tidak pernah samar bagi orang yang memiliki mata hati yang jujur dan berkemauan untuk menjadikan alQur'an sebagai pedoman hidupnya sehingga di dalamnya diketahui dengan jelas mana nilainilai yang harus dilestarikan dan mana yang harus ditinggalkan dengan tetap memohon bimbingan dari Allah Swt.

Diketahui bahwa dilihat dari segi sifat dan coraknya, ilmu pendidikan Islam dapat dibagi menjadi empat bagian. ${ }^{4}$ Pertama, ilmu pendidikan Islam yang bercorak normatif, yaitu kajian ilmu pendidikan yang berbasis pada ajaran yang terkandung dalam al-Qur'an dan alHadis. Dengan begitu, maka al-Qur'an dan al-Hadis dijadikan sebagai sumber penting pendidikan Islam itu sendiri, seperti dijelaskan sebelumnya. Kedua, ilmu pendidikan yang bercorak filosofis, yaitu kajian ilmu pendidikan yang berbasis pada penalaran mendalam yang dilakukan para sarjana muslim. Ketiga, ilmu pendidikan yang bercorak historis-empiris yaitu, kajian ilmu pendidikan Islam yang bertumpu pada informasi yang tercatat dalam sejarah dan dapat dilacak akar-akarnya. Keempat, ilmu pendidikan Islam yang bercorak aplikatif, yaitu kajian ilmu pendidikan Islam yang bertumpu pada penerapan teori dalam praktek belajar mengajar. ${ }^{5}$

Dalam konteks etika dan nilai-nilai pendidikan Islam, maka sumber nilai yang paling sahih adalah al-Qur'an dan al-Sunnah yang dikembangkan dengan ijtihad para ulama. Secara umum, nilai-nilai pendidikan Islam itu meliputi nilai-nilai tauhid, akhlak, sosial kemasyarakatan dan nilai-nilai kebudayaan. $^{6}$

Dengan demikian, dapat disimpulkan bahwa tujuan akhir pendidikan muslim terletak pada perwujudan ketundukan yang sempurna kepada Allah Swt. baik secara pribadi, komunitas, maupun seluruh umat manusia. Tujuan dari pendidikan Islam itu sendiri dalam kenyataanya selaras dengan nilai-nilai yang dibagun. Berbicara pada dataran nilai, seperti diungkap sebelumnya dengan bersumber pada ayat suci al-Qur'an terdapat salah satu surat yang mengandung nilai-nilai pendidikan Islam yang sangat urgen untuk dibahas dalam kaitannya dengan pengembangan mutu dan kualitas Pendidikan Agama Islam ke depan. Nilai yang dimaksud adalah sebagaimana terkandung dalam surat al-'Ashr.

Penelitian tentang nilai-nilai yang terkandung dalam surah ini akan ditelaah dengan menganalisis pemikiran seorang ulama ahli tafsir Islam kontemporer yang sudah tidak asing 
lagi bagi dunia akademis, praktisi dan masyarakat umum. Beliau adalah M.Quraish Shihab dengan karya monumentalnya yaitu kitab tafsir "al-Misbah".

M.Quraish Shihab adalah sosok ulama ahli tafsir kontemporer lulusan Universitas alAzhar Mesir dan mengembangkan model penafsiran tematik yaitu metode penafsiran sesuai dengan tema atau judul yang ditetapkan dalam rangka menafsirkan kandungan al-Qur'an. Salah satu penafsirannya adalah tentang surat al-'Ashr yang menjadi tema sentral dalam penelitian ini.

Dalam penafsirannya terhadap surat al-'Ashr ini misalnya, ketika beliau menafsirkan ayat:

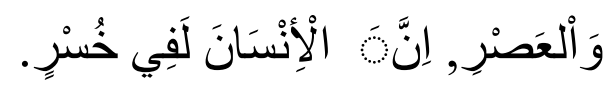

Artinya: "Demi Masa, sesungguhnya manusia benar-benar dalam kerugian."

Ayat tersebut oleh M.Quraish Shihab ditafsirkan bahwa kerugian bagi manusia tidak hanya kerugian parsial (satu persatu), tetapi bisa menjadi kerugian totalitas, oleh kerena itu harus mengisi waktu agar tidak merugi, waktu kalaupun diisi tetapi dengan hal-hal yang negatif manusia akan berada dalam kerugian tersebut. Salah satu cara agar manusia itu bisa terlepas dari kerugian tersebut adalah manusia harus bisa mengisi waktu dengan nilai-nilai positif.

Diantara nilai-nilai positif sekaligus penting untuk menghindarkan diri dari kerugian adalah dengan mendapatkan pengetahuan (knowledge). Pengetahuan yang dimaksud lebih jauh seperti dijelaskan oleh M.Quraish Shihab adalah pengetahuan tentang kebenaran dan kebatilan yang bersumber dari agama. Kalau diruntut lebih jauh, maka apa yang dikemukakan oleh M.Quraish Shihab tersebut berarti ayat ini adalah kategori ayat yang bersifat "kognitif" bila kita mengacu kepada ranah penilaian pendidikan. Inilah salah satu yang melatar belakangi ketertarikan penyusun untuk mengkajinya lebih jauh sehingga didapatkan pemahaman yang utuh tentang surat al-'Ashr tersebut.

Dalam rangka mengkaji surat al-'Ashr ini, Ditipologikan juga dengan tiga lapangan (domain) yang umum dipakai dalam dunia pendidikan dengan istilah "ranah penilaian pendidikan" yaitu: kognitif, afektif dan psikomotorik. Lapangan kognitif meliputi tujuantujuan yang berhubungan dengan berpikir, mengetahui dan memecahkan masalah. Lapangan afektif mencakup tujuan yang berkaitan dengan sikap, nilai dan apresiasi. Sedangkan 
lapangan psikomotorik meliputi tujuan-tujuan yang berhubungan dengan keterampilan mental dan motorik.

Pembagian tiga lapangan taksonomi seperti di atas, secara sederhana adalah klasifikasi standar untuk melihat keberhasilan pengajaran secara instruksional. Karena dengan dasar inilah melahirkan pemikiran untuk mengklasifikasikan tujuan pengajaran dalam tiga lapangan yaitu kognitif, afektif dan psikomotorik

\section{B. Rumusan Masalah}

Berangkat dari latar belakang masalah sebagaimana diuraikan di atas, maka pokok masalah dalam penelitian ini dengan model pertanyaan dapat diungkapkan sebagai berikut:

a. Bagaimana nilai-nilai psiko-edukatif yang terkandung dalam surat al-'Ashr menurut penafsiran M.Quraish Shihab?

b. Bagaimana relevansinya dalam pelaksanaan dan upaya peningkatan kualitas Pendidikan Agama Islam?

\section{Tujuan dan Kegunaan Penelitian}

Penelitian ini bertujuan untuk:

a. Untuk mengetahui nilai-nilai psiko-edukatif Islam yang terkandung dalam surat al-'Ashr dengan mengungkap serta menganalisa pemikiran dari M.Quraish Shihab.

a. Untuk mengetahui relevansi dari nilai-nilai pendidikan yang terkandung dalam surah al'Ashr tersebut dalam rangka mengupayakan peningkatan mutu dan kualitas pendidikan, dapat menambah wawasan keilmuan pendidikan Islam khusus yang berbicara seputar nilai serta berguna pula sebagai sebuah kontribusi keilmuan dalam rangka peningkatan dan pengembangan kualitas sumber daya keilmuan pendidikan Islam.

\section{Metode Penelitian}

Penelitian ini termasuk jenis penelitian pustaka (library research), tentang nilai-nilai pendidikan terutama yang berkaitan dengan nilai-nilai pendidikan yang terkandung dalam surat al-'Ashr dengan menjadikan " Tafsir al-Misbah" sebagai pokok kajian. Sedangkan sifat penelitian ini sendiri berupa penelitian deskriftif - analitis. ${ }^{7}$ Adapun pendekatan yang dipakai dalam penelitian ini adalah pendekatan Paedagogi. Artinya, pembahasan yang ada dalam penelitian ini dianalisis dengan memakai pendekatan Paedagogi dengan menganalisis nilainilai pendidikan yang ada dalam surat al-'Ashr berdasarkan hasil penafsiran M.Quraish 
Shihab dalam tafsir al-Misbah dengan mengacu kepada teorinya Benjamin S. Bloom tentang tujuan pendidikan, sebagaimana yang telah disebutkan dalam latar belakang masalah.

\section{HASIL PENELITIAN}

\section{A. Biografi Hidup dan Aktifitas Keilmuan M. Quraish Shihab}

M.Quraish Shihab lahir pada 16 Februari 1944, di Rappang Sulawesi Selatan. Ia berasal dari keturunan Arab yang terpelajar. Ayahnya Abdul Rahman Syihab (1905-1986) adalah tamatan Jam'iyat al-Khair Jakarta, sebuah lembaga pendidikan Islam tertua di Indonesia yang mengedepankan gagasan-gagasan Islam "modern". Sang ayah selain seorang guru besar dalam ilmu tafsir juga pernah menduduki jabatan Rektor di IAIN Alauddin Ujung Pandang, dan tercatat sebagai salah seorang pendiri Universitas Muslim Indonesia (UMI) Ujung Pandang. ${ }^{8}$

Menurut M.Quraish Shihab, minat ayahnya terhadap ilmu memang cukup besar. Sehingga walaupun sibuk berwiraswasta, beliau selalu berusaha menyisihkan waktunya untuk berdakwah dan mengajar baik di masjid maupun diperguruan tinggi, bahkan sebagian harta kekayaannya baik berupa buku-buku maupun uang disumbangkan kepada lembaga pendidikan. Nampaknya inilah yang kemudian memotivasi M.Quraish Shihab dalam studinya, bahkan minatnya terhadap studi al-Qur'an pun sangat dipengaruhi oleh sang ayah. Sejak kecil, kira-kira sejak beliau berumur enam sampai tujuh tahun sudah harus ikut mendengar ayahnya mengajar al-Qur'an. Pada saat seperti ini ayahnya tidak hanya menyuruh beliau mengaji akan tetapi juga ayahnya menjelaskan sepintas kisah-kisah dalam al-Qur'an. Dari sinilah, muncul benih kecintaan M.Quraish Shihab terhadap studi al-Qur'an.

Hal lain yang tak boleh diabaikan adalah dukungan dan pengaruh sang ibu. Ia senantiasa mendorong anak-anaknya untuk belajar, juga seorang yang sangat "ketat" dalam soal agama. Yakni ia selalu mengukur urusan urusan agama dari sudut al-Qur'an dan al-Hadis. Bahkan ketika M.Quraish Shihab sudah menjadi doktorpun masih sering ditegur oleh ibu. Menyimak latar belakang keluarga seperti itu, tak heran jika minat M.Quraish Shihab terhadap studi agama, khususnya al-Qur'an sangat besar. Hal ini terlihat dari pendidikan lanjutan yang dipilihnya. Setelah menyelesaikan pendidikan dasarnya di Ujung Pandang, M.Quraish Shihab melanjutkan pendidikan menengahnya di kota Malang sambil nyantri di Pondok Pesantren 
Dar al-Hadis al-Faqihiyah. ${ }^{9}$ Pada tahun 1958 dalam usia 14 tahun, Quraish Shihab berangkat ke Kairo, Mesir. Keinginan untuk belajar ke Kairo ini terlaksana atas bantuan beasiswa dari Pemerintah Daerah Sulawesi (waktu itu wilayah Sulawesi belum dibagi menjadi Sulawesi Utara dan Sulawesi Selatan). Mesir dengan Universitas al-Azhar, seperti yang diketahui selama ini, selain sebagai pusat gerakan pembaharu Islam, juga merupakan tempat yang tepat sekali untuk mengambil studi al-Qur'an.

Sejumlah tokoh seperti Muhammad Abduh dan Rasyid Ridha adalah mufassir kenamaan. Tidak heran jika banyak peminat studi ke-Islaman pada waktu itu memilih Mesir sebagai tempat studi dan pusat pembelajaran ilmu-ilmu ke-Islaman. Dalam perjalanan selanjutnya, sekembalinya ke Indonesia, minat M.Quraish Shihab adalah studi al-Qur'an. Karena itu, ketika nilai bahasa Arab yang dicapai ditingkat menengah dianggap kurang dan tidak diizinkan melanjutkan kembali ke Fakultas Ushuluddin Jurusan Tafsir dan Hadis di Universitas al-Azhar, M.Quraish Shihab bersedia mengulang satu tahun. Padahal, dengan nilai yang dicapainya itu, sejumlah jurusan lain dilingkungan Universitas al-Azhar bersedia menerimanya. Bahkan dia juga di terima di Universitas Kairo dan Da>r al-Ulu>m Makkah. Belakangan M.Quraish Sihab mengakui bahwa pilihannya itu ternyata tepat. Sebab selain minat pribadi, pilihannya ini sejalan dengan besarnya kebutuhan umat manusia akan alQur'an dan penafsirannya. ${ }^{10}$

Belajar di Mesir, seperti diketahui, sangat menekankan aspek hafalan. ${ }^{11} \mathrm{Hal}$ ini juga diakui oleh M.Quraish Shihab. Karena itu, jika jawaban ujian tidak persis dengan catatan, nilainya akan berkurang. Tidak heran jika di Mesir kisahnya terutama pada musim hujan banyak orang belajar sambil berjalan-jalan. Suatu fenomena yang tidak ditemukan di Indonesia. Sebab, selain harus memahami teks yang harus dipelajari, mereka harus menghafalnya. Hal yang sama juga dilakukan M.Quraish Shihab ketika belajar di Mesir. Biasanya setelah shalat subuh ia belajar memahami teks, selanjutnya berusaha menghafalnya sambil berjalan-jalan. M.Quraish Shihab nampaknya sangat mengagumi kuatnya hafalan orang-orang Mesir, terutama dosen-dosennya di Universitas al-Azhar. Dalam pandangan M.Quraish Shihab, belajar dengan cara menghafal semacam ini sebenarnya bukan tidak ada lagi segi positifnya. Bahkan menurut beliau nilai positif ini akan semakin bertambah jika kemampuan hafalan itu dibarengi dengan kemampuan analisis. ${ }^{12}$ 
Pada tahun 1967 M.Quraish Shihab meraih gelar Lc (S1) pada Fakultas Ushuluddin jurusan Tafsir Hadis di Universitas al-Azhar. Kemudian ia melanjutkan pendidikannya di Fakultas yang sama pada tahun 1969 dan berhasil meraih gelar M.A untuk spesialisasi Tafsir al-Qur'an. M.Quraish Shihab menulis tesis M.A-nya dengan judul al-I'ja>z al-Tasyri' li alQur'a>n al-Kari>m. Pilihan untuk menulis tesis tentang mu'jizat ini bukan merupakan suatu kebetulan, tetapi didasarkan pada bacaan M.Quraish Shibab terhadap realitas masyarakat muslim yang diamatinya. Menurut beliau, gagasan tentang kemu'jizatan al-Qur'an dikalangan masyarakat muslim telah berkembang sedemikian rupa sehingga sudah tidak jelas lagi, mana yang mu'jizat dan mana yang hanya merupakan keistimewaan al-Qur'an. Mu'jizat dan keistimewaan al-Qur'an menurut M.Quraish Shihab merupakan dua hal yang berbeda, tetapi keduanya masih sering dicampur adukkan bahkan oleh kalangan ahli tafsir sekalipun. ${ }^{13}$

Setelah menyelesaikan program Masternya pada tahun 1970, M.Quraish Shihab kembali ke Indonesia. Selanjutnya, di samping aktif mengajar di IAIN Alauddin Ujung Pandang, beliau juga dipercaya untuk menjabat sebagai pembantu Rektor bidang akademik dan kemahasiswaan pada IAIN yang sama. Setelah sempat mengajar IAIN Alauddin Ujung Pandang, beliau bertolak kembali ke Mesir untuk melanjutkan pendidikan dalam tingkat doctor (S3) dengan mengambil konsentrasi ilmu-ilmu al-Qur'an (Ulu>m al-Qur'a>n). Pendidikan doctor diselesaikan pada tahun 1982 di Universitas yang sama (Universitas alAzhar). M.Quraish Shihab lulus pendidikan Doctor dengan Yudisium (pradikat) Summa Cum Laude disertai penghargaan tingkat pertama di Universitas al-Azhar Mesir. Dengan prestasinya itu, M.Quraish Shihab tercatat sebagai orang yang pertama kali dari Asia Tenggara yang dapat meraih gelar tersebut. ${ }^{14}$

\section{B. Nilai Psiko-educatif dalam surat al-'Ashr}

Sebelum masuk pada analisa tentang surat al-'Ashr, terlebih dahulu dikemukakan surat tersebut secara lengkap, yakni: ${ }^{15}$

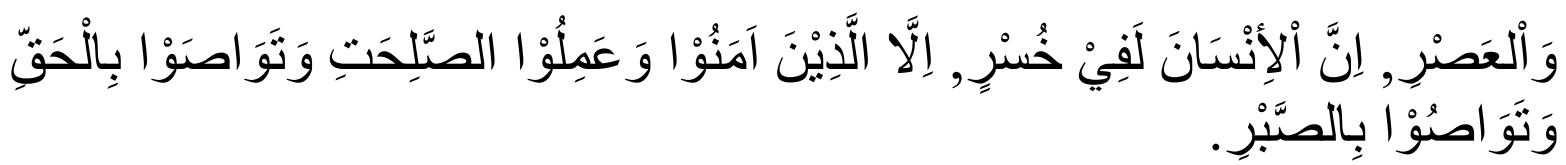

Artinya: " Demi masa, sesungguhnya manusia itu benar-benar berada dalam kerugian, kecuali orang-orang yang beriman dan mengerjakan amal saleh, dan nasehatmenasehati supaya menaati kebenaran dan nasehat-menasehati supaya menetapi kesabaran." 


\section{Nilai Keimanan}

Nilai keimanan dalam kandungan surat al-'Ashr berdasarkan ranah penilaian pendidikan yang ada, masuk pada ranah kognitif dengan mengacu pada unsur-unsur yang ada didalamnya yaitu pengetahuan, pemahaman, penerapan, analisis dan evaluasi.

Dengan demikian, dapat dipahami bahwa ranah kognitif meliputi kecerdasan rasio dan rasa, yang keduanya merupakan wilayah kerja akal yang mampu menerima segala sesuatu yang dapat ditangkap oleh indera dan sesuatu di luar pengalaman empiris. ${ }^{16}$ Dalam akal terdapat rasa yang menimbulkan rasa percaya. Disebutkan bahwa, tidak semua sesuatu yang masuk akal dinamakan rasional karena dalam rasio tidak terdapat unsur rasa, rasio hanya dapat menangkap sesuatu yang bersifat inderawi, sedangkan akal lebih dari itu. ${ }^{17}$

Seorang ahli filsafat ilmu terkenal yakni Plato menempatkan akal sebagai suatu kompas bagi manusia dalam rangka memahami dunia ini. Sementara ahli filsafat lainnya yakni Aristoteles memandang akal sebagai keaktifan untuk tumbuh dan juga sebagai proses pembiakan (vegetatif), bergerak (animal) dan berfikir (tingkat tinggi). Ahli filsafat berikutnya yakni Jhon Dewey sebagai salah seorang penganut aliran filsafat pragmatis, menempatkan akal manusia sebagai alat untuk manusia itu dalam rangka menyesuaikan diri terhadap lingkungan alam sekitarnya serta sebagai alat yang dapat ditugaskan untuk menjalani proses berfikir. $^{18}$

Ketiga pandangan di atas dapat dipahami bahwa, bagi manusia akal dapat menghasilkan berbagai ilmu pengetahuan yang bermanfaat bagi kesejahteraan ummat manusia, menentukan manusia dalam usahanya mencari jalan yang benar atau yang buruk dan memberikan kepuasaan dalam memecahkan persoalan-persoalan dalam hidup. Sehingga Muhammad Abduh memberikan posisi akal sebagai kekuatan tertinggi yang meneliti alam realitas dan alam abstrak yang pada akhirnya memperoleh konklusi (kesimpulan) bahwa segala yang ada pasti ada yang mengadakan yakni Allah Swt. ${ }^{19}$ Demikianlah betapa tingginya kedudukan akal itu bagi manusia yang sekaligus menjadi bukti akan kekuasaan Allah Swt. yang telah menciptakannya untuk kemaslahatan hidup manusia di muka bumi yang ini menjadi sarana penting bagi kehidupannya. Meski demikian, Muhammad Abduh mengakui bahwa pada hakekatnya akal itu punya keterbatasan. Oleh karena itu akal masih berhajat pada wahyu, sebab wahyu dapat memberitahukan hal-hal yang gaib dan dapat mendominasi prinsip-prinsip 
kemasyarakatan yang ada pada manusia dan akalnya tidak mampu menyatakan semua pikirannya. $^{20}$

Dengan demikian, akal bukanlah alat untuk membenarkan wahyu, karena jika kebenaran wahyu didasarkan pada akal, itu berarti akal lebih tinggi posisi atau kedudukannya dari pada wahyu, padahal wahyu itu sendiri kebenarannya adalah bersifat mutlak. Jadi akal bukanlah untuk menciptakan kebenaran, melainkan akal hanya dipergunakan untuk memahami dan menemukan kebenaran, dan untuk ini akal dituntut untuk digunakan seoptimal mungkin, karena pada hakekatnya ia merupakan anugerah Allah Swt. Berikut disebutkan firman Allah Swt. dalam al-Qur'an sebagai berikut: ${ }^{21}$

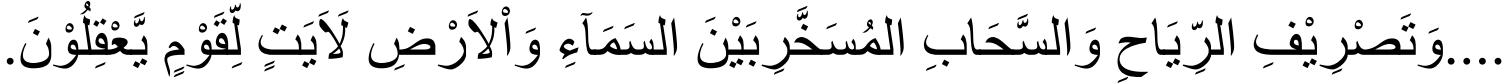
Artinya:..."dan pengisaran angin dan awan yang dikendalikan antara langit dan bumi sungguh terdapat tanda-tanda (keesaan dan kebesaran Allah) bagi kaum yang memikirkan."

Disamping akal yang dianugerahkan oleh Allah swt, kita ketahui bahwa di samping ini masih ada anugerah lain yang saling terkait dengan akal yakni al-qalb (hati). Menurut imam Al-Ghazali, qalb mempunyai dua pengertian, yaitu pengertian fisik dan arti metafisik. Kedua pengertian tersebut dapat dijelaskan sebagai berikut:

1. Arti fisik, al-qalb (hati) yaitu segumpal daging yang berbentuk bulat memanjang yang terletak dipinggir dada sebelah kiri. Al-qalb ini bertugas sebagai media untuk mengatur peredaran darah dalam tubuh manusia untuk memompakannya ke seluruh tubuh manusia itu sendiri. Al-qalb dalam pengertian hati sesungguhnya tidak hanya dimiliki oleh makhluk bernama manusia tetapi juga semua binatang yang bersifat jasmaniah yang dapat ditangkap indera manusia.

2. Arti metafisik, al-qalb adalah batin sebagai tempat berfikir yang sangat bersifat rahasia dan murni, yang merupakan hal yang halus (latifah) manusia selama ia berada di dalam tubuh manusia. Al-qalb ini bertanggung jawab kepada Allah Swt., ditegur, dimarahi serta dihukum. Al-qalb ini akan selalu merasa bahagia apabila selalu berada disisi Allah Swt. dan akan menderita apabila melepaskan diri dari Allah swt. ${ }^{22}$

Al-qalb sebagai bagian pemikiran dan sebagai bagin dari fungsi berfikir di samping akal, dijelaskan dalam firman Allah Swt berikut ini: ${ }^{23}$ 


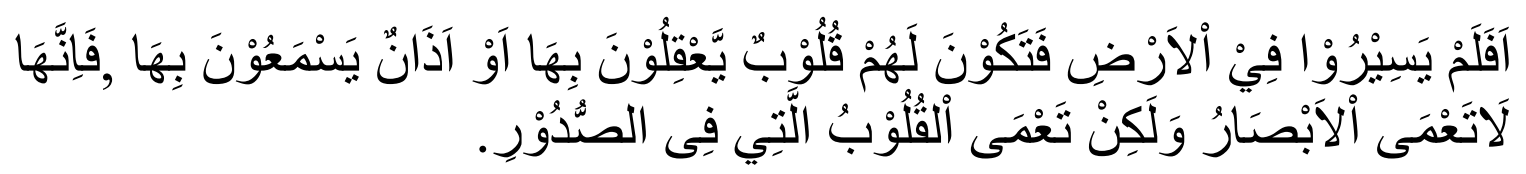

Artinya: " Maka apakah mereka tidak berjalan di muka bumi, lalu mereka mempunyai hati yang dengan itu mereka dapat memahami atau mempunyai telinga yang dengan itu mereka dapat mendengar? Karena sesungguhnya bukanlah mata itu yang buta, tetapi yang buta ialah hati yang di dalam dada."

Al-qalb sebagai wadah fitrah yang sehat, dijelaskan dalam firman Allah Swt yang berikut: $^{24}$

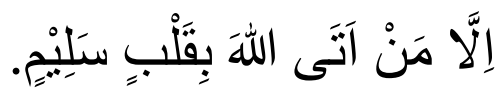

Artinya: "Kecuali orang-orang yang menghadap Allah Swt. dengan hati yang bersih."

Dari beberapa penjelasan tentang akal dan qalb di atas yang dilengkapi dengan nas alQur'an, maka dapat diketahui bahwa perpaduan atau pertautan antara akal dan al-qalb sejatinya merupakan pengetahuan kognitif yang sesungguhnya tentang keesaan Allah (tauhid). Kedua potensi tersebut (akal dan al-Qalb) yang kemudian dalam pendidikan Islam disebut dengan potensi fitrah yang dibawa oleh manusia sejak lahir. ${ }^{25}$

Fitrah sebagai potensi dasar manusia punya dua penegertian, yaitu fitrah sebagai sifat naluri (bawaan) sejak lahir dan fitrah sebagai agama (al-din). Fitrah sebagai sifat bawaan manusia dijelaskan dalam hadis nabi Muhammad Saw. yang berikut ini: ${ }^{26}$

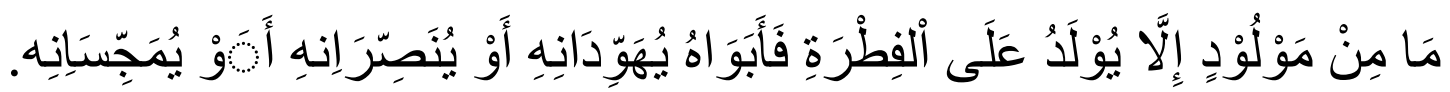

Artinya; "Tidak seorangpun dilahirkan kecuali membawa fitrah, maka usaha kedua orang tuanyalah yang menjadikan dia Yahudi, Nasrani, atau Majusi."

Berikutnya fitrah sebagai sebuah agama (al-din), dijelaskan dalam firman Allah Swt. yang berikut ini: ${ }^{27}$

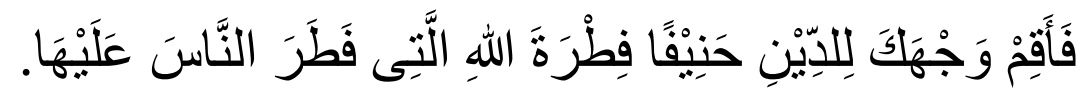

Artinya: "Maka hadapkanlah wajahmu dengan lurus kepada agama (Allah) tetaplah atas fitrah Allah yang telah menciptakan manusia menurut fitrah itu.."

Dengan demikian, istilah fitrah, sebagaimana tersebut dalam al-Qur'an dan al-hadis di atas mengandung makna sebagai berikut:

1. Fitrah bermakna agama (al-din), potensi ini mengandung implikasi kependidikan yang berkonotasi pada paham nativisme. Oleh karena kata fitrah mengandung makna 
"kejadian" yang di dalamnya berisi potensi dasar beragama yang benar dan lurus (al-din al-qayyim) yaitu Islam. Potensi dasar ini tidak dapat diubah oleh siapapun atau lingkungan apapun karena fitrah itu merupakan ciptaan Allah Swt. yang tidak akan mengalami perubahan baik sisi mapun bentuknya dalam tiap pribadi manusia. ${ }^{28}$

2. Fitrah, yang bermakna naluriah (hewan), seperti yang terdapat dalam hadis di atas, maka kita dapat memperoleh petunjuk bahwa fitrah sebagai faktor pembawaan sejak lahir manusia dapat dipengaruhi oleh lingkungan luar dirinya, bahkan ia tak akan dapat berkembang sama sekali bila tanpa adanya pengaruh lingkungan itu.

Dengan potensi fitrah inilah manusia dapat dididik dan berkembang untuk mencapai kebenaran yaitu (din al-Islam). Sedang Islam adalah agama yang mendorong manusia untuk mencari pembuktian melalui penelitian, pemikiran dan merenungkan ke arah iman yang benar. Iman yang benar itu adalah mempercayai, membenarkan, meperhatikan dan menjalankan dalam bahwa iman kepada Allah Swt. percaya dengan sunguh-sungguh akan wujud baik dari segi sifat dan af'al-Nya. Membenarkan akan fenomena-fenomena-Nya, mempertahankan serta berani berkorban demi mempertahankan keyakinannya. Dan menjalankan perintah-perintah-Nya serta meninggalkan larangan-larangan-Nya. ${ }^{29}$

Ini berarti cocok dengan pemikiran M.Quraish Shihab yang mengatakan bahwa iman yang dimaksud di sini adalah pembenaran hati atas apa yang disampaikan oleh nabi Muhammad Saw. Intinya antara lain, dapat disimpulkan dalam rukun iman yang enam itu. Iman sangat sulit digambarkan hakikatnya. Ia dirasakan tetapi sangat sulit untuk melukiskan perasaan itu. M.Quraish Shihab mengatakan bahwa iman itu bagaikan rasa kagum atau rasa cinta, hanya dirasakan oleh pemiliknya dan dalam saat yang sama, si pecinta atau pengagum selalu diliputi oleh rasa tanda tanya, apa gerangan sikap yang dicintai dan dikagumi itu terhadap si pengagum dan pecinta? Seorang yang beriman, bagaikan keadaan seorang yang sedang mendayung perahu di tengah samudera dengan ombak dan gelombang yang dahsyat dan bergemuruh.

Pada saat berada di tengah samudera itu, pasti timbul dalam benak si pendayung suatu ketidakpastian yang menimbulkan tanda Tanya: Dapatkah sampai dipulau yang dituju itu? Demikianlah halnya dengan iman pada tahap-tahap pertama. ${ }^{30}$ Dalam sejarahnya, hal semacam ini pernah dialami oleh Nabi Ibrahim as. menyangkut keimanan tentang hari 
kemudian. Gejolak jiwa beliau yang diliputi oleh tanda tanya itu, diungkapkannya kepada Allah Swt. sebagaimana dalam firman Allah Swt. Yang berikut ini: ${ }^{31}$

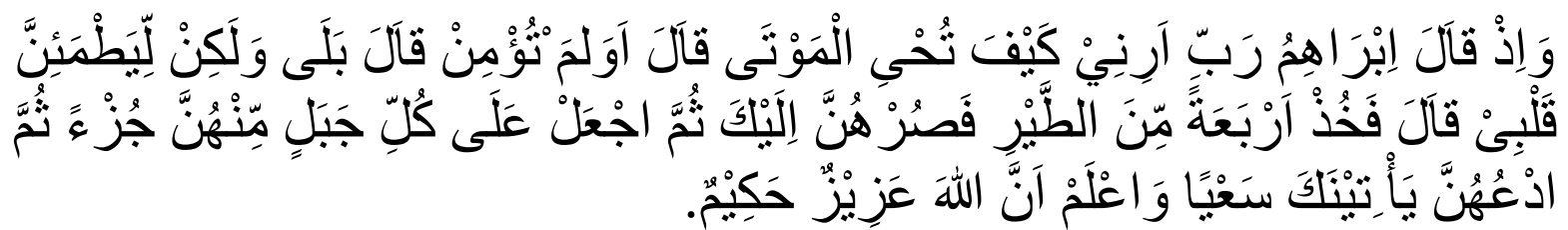

Artinya: "Dan ingatlah ketika Ibrahim berkata: "ya Tuhanku, perlihatkanlah kepadaku bagaimana Engkau menghidupkan orang mati". Allah berfirman: "belum yakinkah kamu?". Ibrahim menjawab: "Aku telah meyakininya, akan tetapi agar hatiku tetap mantap (dengan imanku)". Allah berfirman: (kalau demikian) ambillah empat ekor burung, lalu cincanglah semuanya olehmu. (Allah berfirman):" Lalu letakkan di atas satu bukit satu bagian dari bagian-bagian itu, kemudian panggillah mereka, niscaya mereka akan datang kepadamu dengan segera". Dan ketahuilah bahwa Allah Maha Perkasa lagi Maha Bijaksana."

Penafsiran ayat ketiga di atas dikaitkan oleh M.Quraish Shihab dengan pendapat para ulama kita yang berkenaan dengan pembagian ajaran agama kepada dua sisi, yakni pengetahuan dan pengalaman. Akidah yang wajib diketahui merupakan sisi pengetahuan, sedangkan syari'at merupakan sisi pengalaman. Atas dasar ini, para ulama di atas

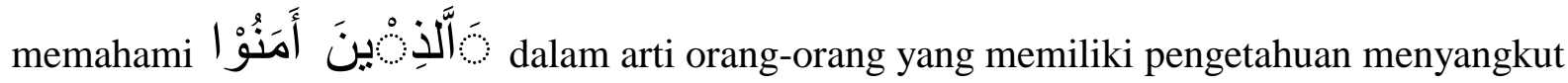
kebenaran. Dan puncak kebenaran adalah pengetahuan tentang ajaran-ajaran agama yang bersumber dari Allah Swt. Jelas bahwa sifat pertama yang dapat menyelamatkan seseorang dari kerugian adalah pengetahuan tentang kebenaran itu. ${ }^{32}$

Berdasarkan pada pengalaman keterangan-keterangan di atas, dapat dipahami bahwa penanaman nilai-nilai iman dalam proses pendidikan merupakan faktor utama dalam rangka memperbaiki perilaku dan kepribadian peserta didik termasuk pelaksananya (guru). Sebab dalam praktek kependidikan tersebut, tidak hanya anak didik yang diharapkan memiliki dan melaksanakan nilai-nilai iman tersebut, tetapi termasuk pelaksana pendidikan dalam arti guru. Guru harus memberikan contoh (modeling) terlebih dahulu sebelum diajarkan pada anak didik. Model ini bukannya tidak memiliki landasan agama, tetapi sebaliknya model ini memiliki landasan agama, sebab inilah yang dipraktekkan oleh nabi Muhammad Saw. pada masa awal. Beliau mencontohkan dengan perbuatan dan tingkah laku yang kemudian menjadi teladan bagi para sahabatnya. ${ }^{33}$ 


\section{Nilai Amal Saleh}

Nilai amal saleh dalam kandungan surat al-'Ashr berdasarkan ranah penilaian pendidikan yang ada, masuk pada ranah psikomotorik dengan mengacu pada unsur-unsur yang ada didalamnya yaitu, persepsi, kesiapan, gerakan terbimbing, gerakan terbiasa, respon kompleks, penyesuaian pola gerakan, kreativitas. disamping itu, masuk juga pada ranah apektif dengan melihat pada unsur-unsur yang ada didalamnya yaitu penerimaan partisipasi penentuan sikap, pembentukan pola hidup. Dalam rangkaian surah al-'Ashar berada pada posisi yang kedua, setelah posisi pertama yakni iman. Selain iman, amal saleh juga menjadi syarat yang tidak dapat ditawar-tawar, dengan kata lain keberadaan amal saleh mutlak diperlukan oleh manusia supaya ia terlepas dari kerugian.

Dalam istilah psikologi, motorik diartikan sebagai istilah yang menunjuk pada hal keadaan dan kegiatan yang melibatkan otot-otot dan gerakan-gerakannya. Secara singkat, dapat dipahami bahwa motor adalah segala keadaan yang meningkatkan atau menghasilkan stimulasi (rangsangan) terhadap organ-organ fisik. ${ }^{34}$

Sementara Chalijah Hasan mengatakan bahwa, yang di maksud dengan psikomotorik adalah kemampuan yang menyangkut kegiatan otot dan kegiatan fisik, yaitu tekanan kemampuan yang menyangkut penguasaan tubuh dan gerak. ${ }^{35}$

Dari dua pengertian di atas, dapat dipahami bahwa dimensi psikomotorik bertujuan untuk mengembangkan keterampilan fisik (jasmani) manusia melalui sarana pendidikan. Termasuk bagian dari keterampilan fisik (jasmani) itu adalah memelihara diri dari segala sesuatu yang dapat mengancam kesehatan fisik para pelajar dan juga pendidik. Ini menjadi kewajiban tersendiri bagi setiap individu dikarenakan fungsi manusia di muka bumi sebagai khalifah (wakil Tuhan), maka untuk terlaksananya tugas tersebut (khalifah), maka kesehatan dan kekuatan fisik menjadi sangat menentukan. Alasannya karena tugas kekhalifahan tidak akan berhasil manakala jasmani muslim berada dalam posisi lemah. Oleh sebab itu, terdapat firman Allah Swt. dalam al-Qur'an, yakni sebagai berikut : ${ }^{36}$

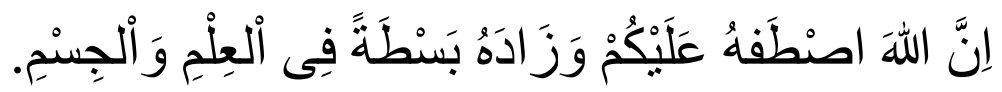

Artinya: "... Sesungguhnya Allah Swt. memilih dia di antara kamu (sebagai raja) atas kamu serta menambahinya dengan ilmu yang luas dan tubuh yang kuat perkasa". 
Fisik yang sehat dan kuat merupakan salah satu ciri muslim yang sempurna, sebab kesehatan jasmani erat dengan kesehatan rohani (mental). Jasmani yang sehat akan melahirkan amal saleh, sedang mental yang sehat akan melahirkan iman yang benar. Dengan demikian, keterampilan fisik sebagai ranah psikomotorik tidak dimaksudkan berhenti sebatas tubuh semata. Tetapi lebih diarahkan sebagi energi potensial yang muncul dari tubuh, terungkap dalam jiwa dan terlaksana dalam perbuatan yang berbentuk amal saleh. Pertanyaannya kemudian apakah itu amal saleh?. Secara sederhana amal saleh adalah semua perbuatan-perbuatan yang baik dan membawa kebaikan baik untuk diri pribadi dan juga bagi sesama. Perbuatan baik sebagai perwujudan amal saleh juga merupakan realisasi dari taqwa yang menjadi salah satu dari kunci ke-islaman setelah iman dan Islam.

Taqwa secara sederhana diartikan sebagai "takut kepada Tuhan". Arti sesungguhnya dari taqwa adalah menjunjung tinggi segala perintah-perintah Tuhan dan menjauhi segala apa yang menjadi larangannya. ${ }^{37}$ Dengan demikian amal saleh adalah realisasi dari taqwa itu sendiri.

M.Quraish Shihab dalam penafsirannya menyebutkan bahwa, kata عَمِلَ digunakan oleh al-Qur'an untuk menggambarkan penggunaan daya manusia, yaitu daya pikir, fisik, kalbu, dan daya hidup yang dilakukan dengan sadar oleh Manusia dan Jin. ${ }^{38}$ Sedangkan kata

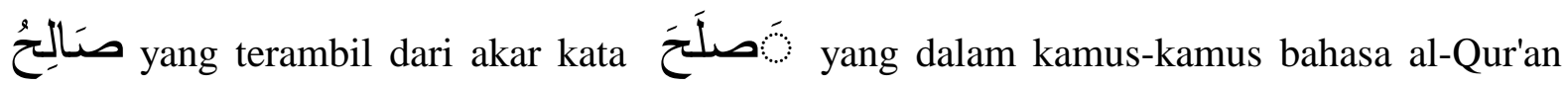

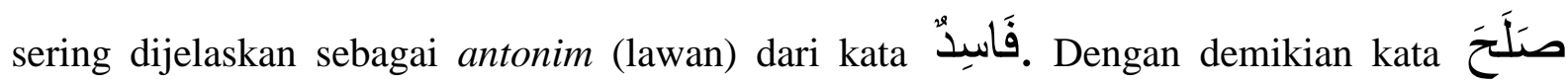
diartikan sebagai terhentinya kerusakan. Kata ini diartikan juga dengan manfaat dan sesuai.

Amal saleh adalah pekerjaan yang apabila dilakukan terhenti atau menjadi tiada-akibat pekerjaan tersebut-suatu mudarat (kerusakan), atau dengan dikerjakannya diperoleh manfaat atau kesesuaian. Amal saleh adalah segala perbuatan yang berguna bagi pribadi, keluarga, masyarakat atau kelompok dan manusia secara keseluruhan. Amal saleh adalah segala perbuatan yang sesuai dengan dalil akal, al-Qur'an, dan Sunnah Nabi Mahammad Saw, melakukan sesuatu upaya agar nilai-nilai yang terdapat pada sesuatu tetap lestari sehingga ia dapat berfungsi sebagaimana mestinya. ${ }^{39}$

Setiap amal saleh harus memiliki dua sisi. Pertama wujud amal, yang biasanya terlihat di alam nyata. Di sini orang lain dapat memberikan penilaian sesuai dengan kenyataan yang 
dilihatnya. Penilaian baik diberikan manakala kenyataan yang dilihatnya itu menghasilkan manfaat dan menolak mudarat. Sisi kedua adalah motif pekerjaan itu. Mengenai sisi ini, hanya Allah Swt. yang dapat menilainya. Sebagaimana Rasulullah Saw. Bersabda: ${ }^{40}$

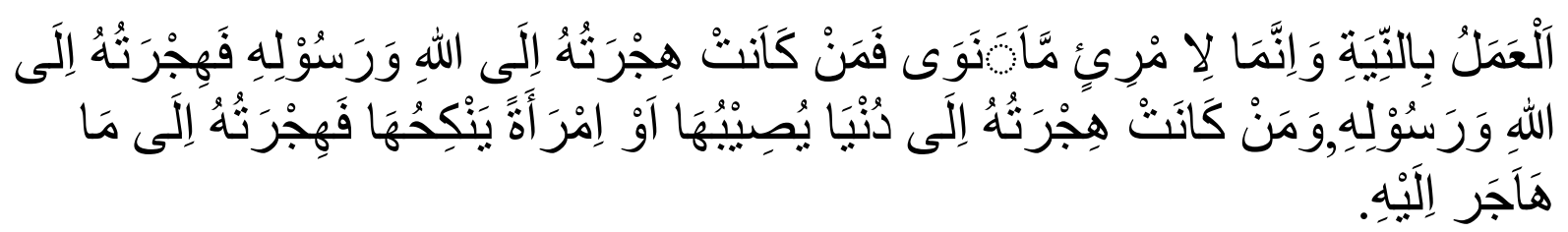

Artinya: "Setiap pekerjaan sesuai dengan niatnya, dan bagi tiap-tiap pekerjaan itu, tergantung apa yang diniatkan, maka siapa yang hijrahnya kepada Allah dan Rasulnya, maka hijrahlah ia kepada Allah dan Rasul. Siapa yang hijrahnya karena dunia, maka ia mendapatkannya atau perempuan maka ia menikahinya, maka hijrahlah ia kepada yang dihijrahinya."

Dengan demikian, dapat dikatakan bahwa di sisi Allah Swt., nilai suatu pekerjaan bukan semata-mata dari bentuk lahiriah yang tampak di alam nyata, tetapi yang lebih penting adalah niat pelakunya. Karena itu, dapat dimengerti mengapa kalimat "amal saleh" banyak sekali digandengkan dengan "iman", karena iman inilah yang menentukan arah dan niat seseorang ketika melakukan suatu amal. Dalam pandangan Islam pula, antara jasmani dan rohani tidak bisa dipisiahkan, seperti mendengar, melihat, merasa dan lain-lain.semua itu merupakan aktifitas indera manusianamun tidak bisa lepas dari wujud rohaninya. Ini terbukti secara rohaniah bahwa semua perbuatan itu mengandung nilai-baik atau buruk secara agama dan tergantung juga bagaimana niatnya dalam berbuat sesuatu itu. Apabila ada menusia yang dia mendengar tapi tidak merasaklan apa-apa dalam hatinya, melihat tetapi tidak ada kesadaran apapa dalam hatinya, semua itu tidak membawa arti apa-apa pada dirinya. Maka orang-orang yang model ini di sindir oleh Allah Swt. dalam firman-Nya: ${ }^{41}$

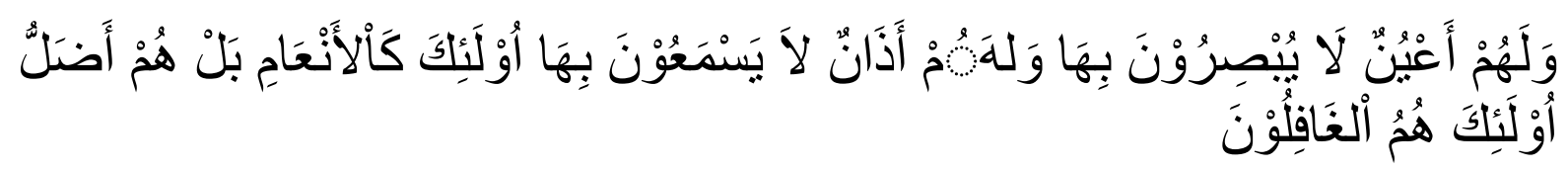

Artinya; "Dan mereka punya mata tetapi tidak menggunakannya untuk melihat, dan mempunyai telinga, tetapi tidak menggunakannya untuk mendengar, mereka bagaikan binatang, bahkan lebih buruk dari itu, mereka itulah orang-orang yang lalai."

Ayat di atas memberikan pengertian bahwa potensi-potensi yang diberikan oleh Allah Swt. kepada manusia namun tidak disyukuri oleh manusianya dalam arti tidak dimanfaatkan sesuai dengan syari'at yang sudah ditetapkan oleh Allah Swt., maka manusia seperti ini (yang 
tidak memanfaatkan potensinya dengan baik) tidak ada bedanya lagi dengan hewan atau binatang, dan bisa jadi manusianya itu malah lebih buruk lagi daripada binatang. Alasannya adalah karena manusianya tidak menjalankan aktifitas-aktifitas sesuai dengan tuntunan Allah Swt.

Di sinilah pentingnya pendidikan Islam untuk membiasakan dan melatih daya psikomotorik anak-anak didik dengan menanamkan nilai-nilai ilahiyah, agar potensi-potensi yang dimiliki itu dapat dikembangkan sesuai dengan tujuan yang ditetapkan oleh Allah Swt, baik dalam hal menjalankan syari'at maupun dalam hal memenuhi kebutuhan- kebutuhan hidupnya.

\section{Nilai Nasehat Tentang Kebenaran dan Kesabaran}

Nilai nasehat menasehati dalam kandungan surat al-'Ashr berdasarkan ranah penilaian pendidikan yang ada, masuk pada ranah afektif dengan mengacu pada unsur-unsur yang ada didalamnya yaitu, penerimaan, partisipasi penentuan sikap dan pembentukan pola hidup. Disamping itu, masuk juga pada ranah psikomotor dengan melihat pada unsur-unsur yang ada didalamnya yaitu persepsi, kesiapan, gerakan terbimbing, gerakan terbiasa, respon kompleks, penyesuaian pola gerakan dan kreativitas.

Dalam bahasa psikologi pendidikan, afektif itu meliputi tujuan-tujuan yang berkaitan dengan sikap, nilai, minat dan apresiasi. Ciri khasnya terletak dalam belajar menghayati nilai dari objek-objek yang dihadapi melalui alam perasaan, entah itu berupa berupa orang, benda atau kejadian/peristiwa. Ciri lain terletak dalam belajar mengungkapkan perasaan dalam bentuk apresiasi yang wajar. Dalam merasa orang langsung menghayati apakah suatu obyek baginya berharga/bernilai atau tidak. ${ }^{42}$

Menurut Amin Abdullah, aspek kognitif ini sangat perlu mendapatkan perhatian khsusus dalam pendidikan Islam. ${ }^{43}$ Namun ketiganya (kognitif, psikomotorik dan afektif), tidak bisa dipisah-pisahkan. Sebabnya adalah, ketiga aspek tersebut merupakan satu kesatuan yang saling berhubungan antara yang satu dan lainnya. Buktinya adalah surat al-'Ashr misalnya, yang menjadi fokus kajian penyusun, dijelaskan bahwa iman sebagai nilai kognitif, tidak bisa tanpa diwujudkan dengan amal saleh, maka amal saleh sebagai nilai psikomotorik, amal saleh tidak lengkap juga sebelum seruan tentang kebenaran dan kesabaran, dan inilah nilai afektif. 
Tentang nasehat dalam hal kebenaran dan kesabaran, M.Quraish Shihab menjelaskan bahwa saling berwasiat menyangkut haq (kebenaran) yang diperintahkan ini mengandung makna bahwa seseorang berkewajiban untuk mendengarkan kebenaran dari orang lain serta mengajarkannya kepada orang lain. Seseorang belum terlepas dari kerugian bila sekedar beriman, beramal saleh dan mengetahui kebenaran itu untuk dirinya, tetapi ia juga berkewajiban menyampaikannya kepada orang lain. Hal lain yang merupakan syarat untuk dapat membebaskan seseorang dari kerugian total adalah saling berwasiat tentang kesabaran. ${ }^{44}$

Selanjutnya M.Qurais Shihab menjelaskan bahwa Sabar adalah menahan kehendak hawa nafsu demi mencapai sesuatu yang baik atau lebih baik. Secara umum kesabaran dapat dibagi dalam dua bagian pokok, yaitu sabar jasmani dan sabar rohani. Yang pertama adalah kesabaran dalam menerima dan melaksasnakan perintah-perintah keagamaan yang melibatkan anggota tubuh, seperti sabar dalam melaksanakan ibadah haji yang mengakibatkan keletihan atau sabar dalam peperangan membela kebenaran, termasuk pula dalam bagian ini sabar dalam menerima cobaan-cobaan yang menimpa jasmani seperti penyakit, penganiayaan dan semacamnya. Sedangkan yang kedua adalah sabar rohani yang menyangkut kemampuan menahan hawa nafsu yang dapat mengantar kepada keburukan, seperti menahan amarah, menahan hawa nafsu yang bukan pada tempatrnya. ${ }^{45}$ Senada dengan M.Quraish Shihab yakni dari Muh\}ammad 'Ali as-S \}abu>ni yang mengatakan bahwa antara berwasiat tentang kebenaran dan berwasiat tentang kesabaran, harus dengan berkesinambungan (kontinuitas). Inilah yang menjadi rahasia kenapa kemudian bentuk fi'il dalam ayat tersebut $\left(\right.$ وَنَوَ اصَنْو ا) di ulang dua kali (bitakri>r al-fi'li). ${ }^{46}$

Tentu tidak dapat diragukan lagi, betapa pentingnya penanaman nilai- afektif ini bagi setiap peserta didik. Maka dalam pendidikan Islam, nilai ini ditekankan kepada peserta didik, agar peserta didik itu memiliki kepekaan yang artinya adalah anak didik dapat tumbuh rasa cinta kasihnya, perasaan sayang yang ini sangat bermanfaat dalam menjalani kehidupannya dalam bermasyarakat dengan baik dan benar sesuai dengan nilai-nilai ilahiyah yang telah ditanamkan sebelumnya. Ini pulalah yang digariskan oleh Allah Swt. dalam surat al-'Ashr, dalam keseluruhan maknanya adalah saling terkait yang menandakan bahwa masing-masing nilai kognitif, psikomotorik dan afektif itu hanya dapat dibedakan saja tetapi tidak bisa 
dipisah-pisahkan ketiganya karena memang ketiganya saling mendukung. Dalam upaya menerapkan ranah afektif ini, minimalnya harus terlihat adanya penerimaan dari anak didik, partisipasinya dan akhirnya adalah pembentukan pola hidupnya sesuai dengan nilai-nilai yang terkandung. ${ }^{47}$

\section{Kesimpulan}

Dari pembahasan di atas, ada beberapa kesimpulan yang dapat dikemukakan kaitannya dengan nilai-nilai edukatif dalam surat al-'Ashr dengan mengkritisi pemikiran M.Quraish Shihab dalam tafsir al-Misbah, yakni sebagai berikut:

1. Bahwa dalam surat al-'Ashr mengandung nilai-nilai kognitif, afektif dan psikomotorik yang merupakan ranah tujuan dalam sistem pendidikan.

2. Dalam kenyataannya bahwa iman dalam kandungan surat al-'Ashr itu menempati nilai kognitif dalam ranah penilaian pendidikan, amal saleh menempati nilai atau sebagai perwujudan nilai psikomotorik dan saling bernasehat dalam kebenaran dan juga kesabaran menempati atau sebagai perwujudan nilai afektif.

3. Iman sebagai nilai kognitif, amal saleh sebagai nilai psikomotorik dan saling bernasehat dengan kebenaran dan kesabaran sebagai nilai afektif relevan dengan nilai-nilai yang dikandung dalam pendidikan agama Islam yakni nilai tauhid, sosial dan akhlak. 


\section{End Note}

${ }^{1}$ Yang dimaksud dengan pendidikan dan pengajaran yang seluas-luasnya adalah pendidikan yang bukan hanya berarti formal seperti di sekolah, melainkan juga informal non formal. Yaitu pendidikan dan pengajaran yang dapat dilakukan oleh siapa saja yang memiliki ilmu dan keahlian kepada siapa saja yang membutuhkan dimana saja mereka berada; mulai lahir hingga akhir hayat, menggunakan seluruh sarana apa saja dan dengan cara apa saja. Lihat dalam H. Abuddin Nata, Asal- Usul Kejadian Manusia (Tafsir surat al-'Alaq dan al-Mu'minun ayat 12-17), dalam Tafsir Ayat-Ayat Pendidikan (Tafsi >r al-Tarba>wi), Jakarta: PT.Raja Grafindo Persada, 2002), hlm. 35.

${ }^{2}$ Ibid, hlm. 36.

${ }^{3}$ Al-Qur'an Surat al-Baqarah (2:185) Ayat ini memberikan penjelasan bahwa al-Qur'an merupakan petunjuk bagi manusia (lebih-lebih bagi orang-orang yang beriman), dan menerangkan antara yang baik dan yang tidak baik. Lihat selengkapnya dalam Departemen Agama RI, al-Qur'an Dan Terjemahnya, (Bandung: Diponegoro, 2004).

${ }^{4}$ Azyumardi Azra, Tafsir Ayat-Ayat Pendidikan, (Tafsir al-Ayat al-Tarbawi), (Kata Pengantar), (Jakarta: PT. Raja Grafindo Persada, 2002), hlm. Vii.

${ }_{6}^{5}$ Ibid, hlm. Viii.

${ }^{6}$ Achmadi, Ideologi Pendidikan Islam, ..., hlm. 122

${ }^{7}$ Deskripsi adalah suatu metode yang menggunakan pencarian suatu fakta dengan interpretasi yang cermat dan tepat. Sedangkan analisis adalah menguraikan data secara cermat dan terarah. Lihat dalam Muhammad Nazir, Metode Penelitian, (Jakarta: Ghalia Indonesia, 1998), hlm. 63.

${ }^{8}$ M. Quraish Shihab, Membumikan Al-Qur'an, Fungsi dan Peran Wahyu dalam Kehidupan Masyarakat (Bandung: Mizan, 1997), hlm.6.

${ }^{9}$ Lihat dalam Ibid.

${ }^{10}$ Rifyal Ka'bah, "Banyak yang Harus Dibenahi dalam Beberapa Persoalan Tentang Studi Islam di Barat", Jurnal Ulum al-Qur'an, vol. 3 no. V, 1994, hlm.

${ }^{11}$ A.Lutfi as-Syaukani, "Belajar Islam di Timur dan Barat: Ketidak Berbandingan Produksi". Dalam Jurnal Ulum alQur'an vol.3, no.V, 1994, hlm. 22.

12 Arief Subhan, "Menyatukan Kembali al-Qur'an dan Umat, Menguak Pemikiran M.Quraish Shihab",dalam Jurnal Ulum al-Qur'an, vol. IV, no.5 1995, hlm. 14.

${ }^{13}$ Lebih lanjut tentang pengertian mu'jizat menurut Islam dapat dilihat dalam M.Quraish Shihab, Mu'jizat al-Qur'an Ditinjau dari Aspek Kebahasaan, Isyarat Ilmiyah dan Pemberitaan Ghaib (Bandung: Mizan, 1997), hlm. 23.

${ }^{14}$ M. Quraish Shihab, Wawasan al-Qur'an: Tafsir Maudhu'I atas Pelbagai Persoalan Umat, (Bandung: Mizan, 2007), hlm. i.

${ }^{15}$ Q. S.al-'Ashr (103: 1-3).

${ }^{16}$ Anharuddin, Evolusi Manusia dan Konsepsi Islam, (Bandung; Gema Risalah Press, 1987), hlm. 2.

${ }^{17}$ Ibid.

${ }^{18}$ M. Said, Mendidik dari Zaman ke Zaman, (Jakarta: Dian Rakyat, 1963), hlm. 97-101

${ }^{19}$ Lihat dalam Harun Nasution, Muhammad Abduh dan Teologi Rasional Mu'tazilah, (Jakarta: UI Press, 1987), hlm. 48-49.

${ }^{20}$ Untuk keterangan selanjutnya lihat dalam Ibid.

${ }^{21}$ Q.S. al-Baqarah (2): 164.

22 Lihat Muhaimin dan Abd Mujib, Pemikiran Pendidikan Islam, Kajian Filosofis dan Kerangka Dasar Operasionalnya, (Bandung: Trigenda Karya, 1993), hlm. 39.

${ }^{23}$ Q.S. al-Hajj (22: 46).

${ }^{24}$ Q.S. asy-Syu'ara (26: 89).

25 Akal dan al-Qalb sebagai potensi yang merupakan fitrah manusia sejak lahir juga diakui oleh sejumlah pakar pendidikan Islam seperti Hasan Langgulung. Lihat dalam Hasan Langgulung, Beberapa Pemikiran Tentang Pendidikan Islam, (Bandung: Al-Ma'arif, 1995), hlm. 22.

ISLAMIC COUNSELING VOL 1 NO. 02 TAHUN 2017, STAIN CURUP 
${ }^{26}$ Imam Muslim, Sahih Muslim, Juz VIII, (Beirut: Dar al-Ma'arif, t.t), hlm. 53.

${ }^{27}$ Q.S. al-Rum (30: 30).

${ }^{28}$ H. M.Arifin, Ilmu Pendidikan Islam, Suatu Kajian Teoretis dan Praktis Berdasarkan Pendekatan Inter Disipliner, (Jakarta: Bumi Aksara, 1994), hlm. 89.

${ }^{29}$ Lihat dalam muqaddimah Mahmud Syaltut dalam, Islam Aqidah dan Syari'ah, terj. Fachruddin HS. (Jakarta: Bumi Aksara, 1994), hlm. ix-dst.

${ }^{30}$ M.Quraish Shihab, Tafsir al-Misbah: Pesan Kesan dan Keserasian al-Qur'an, (Jakarta: Lentera Hati, 2000), hlm. 499.

${ }^{31}$ Q.S. al-Baqarah (2): 260

${ }^{32}$ M.Quraish Shihab, Tafsir al-Misbah:..., hlm. 500

${ }^{33}$ Zuhairini, dkk, Sejarah Pendidikan Islam, (Jakarta: Bumi Aksara, 19995), hlm. 27.

${ }^{34}$ Muhibbin Syah, Psikologi Pendidikan Suatu Pendekatan Baru, (Bandung: Remaja Rosda Karya, 1995), hlm. 59.

${ }^{35}$ Chalijah Hasan, Dimensi-Dimensi Psikologi Pendidikan, (Surabaya: Al-Ikhlas, 1994), hlm. 134

${ }_{37}^{36}$ Q.S. al-Baqarah (2: 247).

37 M. Dawam Rahardjo, Ensiklopedi Al-Qur'an: Tafsir al-Qur'an Berdasarkan Kata-kata Kunci, (Jakarta: Paramadina, 2002) hlm.155.

${ }^{38}$ M.Quraish Shihab, Tafsir al-Misbah, ... hlm.500.

${ }^{39}$ Ibid.

${ }^{40}$ Ima $>$ m al-Bukha>ri, Słahi>h al-Bukha $>r i$, ditahqiq oleh Abdul 'Azi>z bin Abdullah bin Ba>z, (Beirut: Da>r alFikr, 1994), VI: 144.

${ }^{41}$ Q.S. al-'Araf (7:179).

${ }^{42}$ Lihat dalam Chalijah Hasan, Dimensi-Dimensi Psikologi Pendidikan, (Surabaya; al-Ikhlas, 1994), hlm. 133.

${ }^{43}$ M.Amin Abdullah, Problem Efistemologis Metodologis Pendidikan Islam, dalam Abdul Munir Mulkhan, (ed), Rekonstruksi Pendidikan dan Tradisi Pesantren: Relegiusitas IPTEK, (Yogyakarta : Pustaka Pelajar, 1998), hlm. 56.

${ }^{44}$ M.Quraish Shihab, Tafsir al-Misbah, .... ,hlm. 504.

${ }^{45}$ Ibid.

${ }^{46}$ Muh \}ammad 'Ali as-S \}abu>ni, S Jafwa at-Tafa $>$ si $>r$, (Mesir: Da>r al-S \}abu>ni, t.t), hlm. 600.

${ }^{47}$ H.Ramayulis, Ilmu Pendidikan Islam, (Jakarta: Kalam Mulia, 2006), hlm. 147. 